\title{
Technè
}

La science au service de l'histoire de l'art et de la préservation des biens culturels

43 | 2016

Une Europe de la recherche en sciences du patrimoine

\section{Genèse des programmes européens LabS TECH et Eu-ARTECH}

Jean-Louis Boutaine

\section{(2) OpenEdition}

Journals

Édition électronique

URL : http://journals.openedition.org/techne/631

DOI : 10.4000/techne.631

ISSN : 2534-5168

Éditeur

C2RMF

Édition imprimée

Date de publication : 1 août 2016

Pagination : 8-20

ISBN : 978-2-7118-6338-9

ISSN : $1254-7867$

Référence électronique

Jean-Louis Boutaine, «Genèse des programmes européens LabS TECH et Eu-ARTECH », Technè [En ligne], 43 | 2016, mis en ligne le 19 décembre 2019, consulté le 28 juillet 2020. URL : http:// journals.openedition.org/techne/631; DOI : https://doi.org/10.4000/techne.631

La revue Technè. La science au service de l'histoire de l'art et de la préservation des biens culturels est mise à disposition selon les termes de la Licence Creative Commons Attribution - Pas d'Utilisation Commerciale - Pas de Modification 4.0 International. 


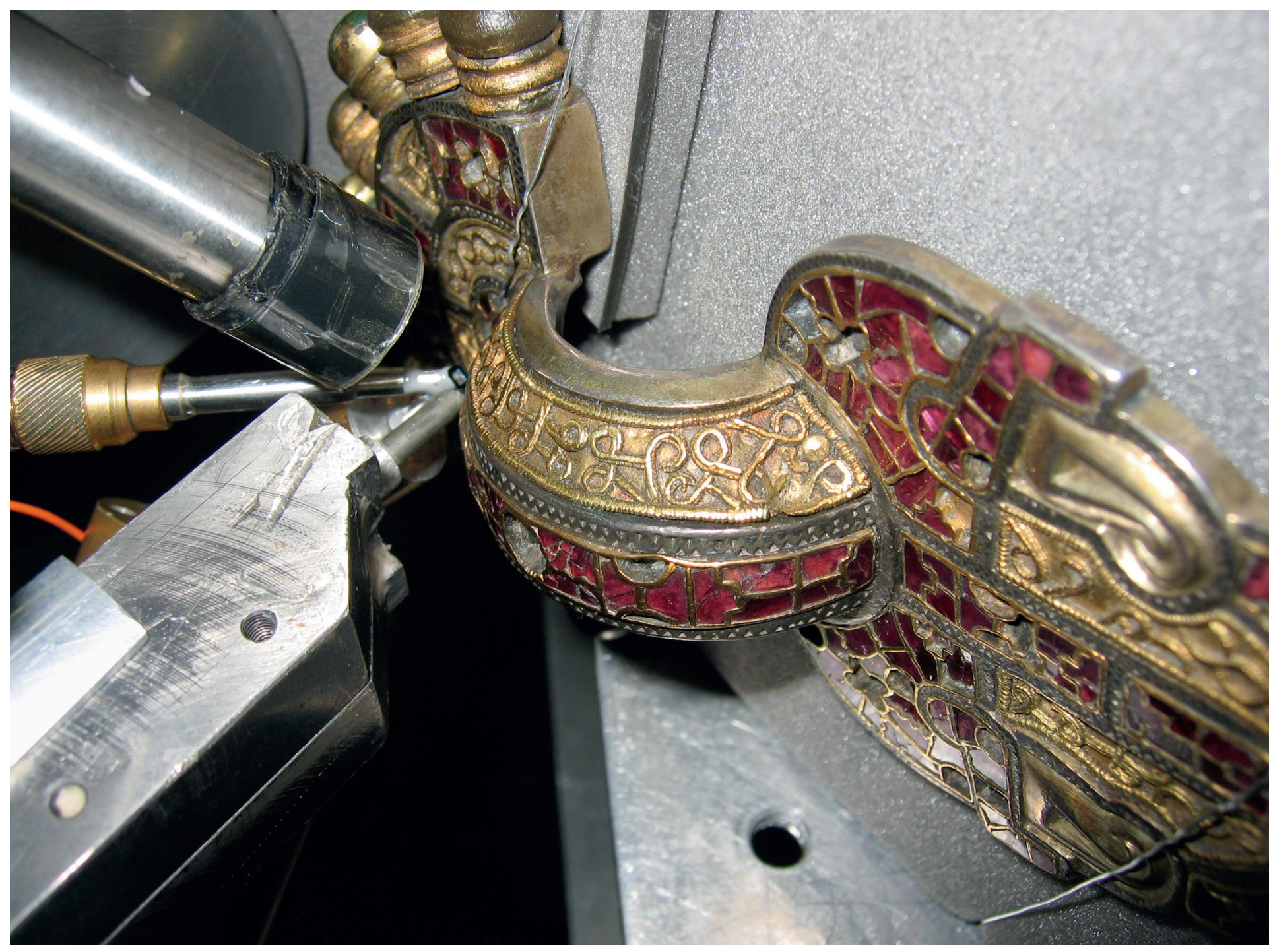

Fig. 1. Fibule mérovingienne provenant du site de Wittislingen et conservée à la Archäologische Staatssammlung de Munich. Les grenats incrustés sont analysés par la méthode PIXE sur AGLAE pour déterminer leur provenance. Merovingian fibula coming from the Wittislingen site and conserved at the Archäologische Staatssammlung in Munich. The inlaid garnets are analyzed by PIXE at the AGLAE to determine their provenance. (c) C2RMF/T. Calligaro. 
Jean-Louis Boutaine

\title{
Genèse des programmes européens LabS TECH et Eu-ARTECH
}

\author{
Genesis of European research projects LabS \\ TECH and Eu-ARTECH
}

Résumé. Plusieurs institutions européennes, dans le cadre de Programmes Cadres pour la Recherche et le Développement successifs de la Commission européenne, ont progressivement coopéré, à travers un réseau puis deux projets de recherche successifs (de 2001 à 2014), en ayant comme objectif de construire un réseau réparti, ouvert et coopératif, permettant à des équipes européennes de développer, appliquer, partager et rendre accessibles des instruments innovants, des méthodologies, des procédures pour l'examen, l'analyse, la restauration et la conservation des cuvres appartenant au patrimoine culturel européen. Cet article présente les étapes de ces projets, l'organisation des consortiums successifs, les différents participants impliqués, quelques éléments relatifs à l'activité de mise en réseau, aux accès transnationaux, aux infrastructures de recherche ou aux instruments d'analyse, ainsi que quelques exemples de recherche coopérative menés à bien.

Mots-clés. Projets de recherche européens, patrimoine culturel, collections de musées, techniques analytiques, conservation-restauration.

\begin{abstract}
A cluster of European institutions, in the frame of successive Research Framework Programmes of the European Commission, have progressively cooperate through a network, and two successive research projects (from 2001 to 2014), with the objective to build a distributed, open and collaborative network, permitting to European teams to develop, apply, share and make available innovative instruments, methodologies, procedures for the examination, analysis, restoration and conservation of artefacts belonging to the European cultural heritage. The paper presents the different steps of these projects, the organisation of the successive consortiums, the different involved participants, some details concerning the networking activity, the transnational access to research infrastructures or set of instruments and some examples of co-operative research.
\end{abstract}

Keywords. European research projects, cultural heritage, museum collections, analytical techniques,

conservation-restoration.

\section{Rappel sur quelques projets européens dans le domaine de la conservation du patrimoine culturel}

L'Europe est le continent majeur en science de la conservation, avec un très grand nombre d'acteurs : établissements patrimoniaux publics, universités et établissements d'enseignement supérieur, musées, bibliothèques, archives, institutions archéologiques, associations, coopératives, centres techniques, entreprises privées... Les coopérations entre ces acteurs sont nombreuses : coopérations bilatérales, réseaux européens et projets de recherche, soit dans le cadre des PCRD successifs (Programmes Cadres pour la Recherche et le Développement), soit à travers des actions COST (European Cooperation in Science et Technology), accueil de thésards, contrats de postdoctorat, chercheurs invités...

La Commission européenne, par sa Direction Générale « Recherche », a, depuis 1989, soutenu une politique de diffusion des connaissances, de création de réseaux, de recherche

\section{Reminder on some European research projects in the cultural heritage conservation area}

Europe is the major continent as far as conservation science is concerned, with a large number of participants: public cultural heritage institutions, Universities and higher education establishments, museums, libraries, archives, archaeological institutions, associations, cooperatives, technical centres, private companies... There are many types of cooperation between these actors: bilateral cooperation, European networks and research projects, either in the frame of the successive FPs (Framework Programmes for Research and Development), or through COST actions (European Cooperation in Science and Technology), fellowships for thesis students, post-docs, invited scientists...

Since 1989, the European Commission, via its DirectorateGeneral for Research and Innovation has promoted a policy of knowledge distribution, networks constitution, collaborative research, access for scientists to large research facilities. This

Jean-Louis Boutaine, ancien chef du département Recherche du Centre de Recherche et de Restauration des Musées de France (C2RMF) (jean-louis.boutaine@wanadoo.fr). 
collaborative, d'accès des chercheurs aux installations de recherche. Ceci s'est traduit par de nombreux appels d'offres. Michel Chapuis (Direction de la Recherche de la Commission Européenne) a publié une synthèse de ces projets. Environ 100 projets ont été financés sur la période allant de 1991 à 2009 dans le cadre des $3^{\mathrm{e}}$ au $7^{\mathrm{e}}$ PCRD $^{1}$. Il est possible d'accéder au descriptif de ces projets sur la base Cordis ${ }^{2}$ qui constitue une source très riche pour nouer des collaborations et obtenir des résultats de recherche.

Parallèlement, une structure intergouvernementale créée en 1971 dénommée COST (European Cooperation in Science et Technology) ${ }^{3}$, regroupant 36 pays, a financé des réseaux entre scientifiques européens, dont certains étaient dédiés aux thématiques «sciences et techniques au service du patrimoine culturel ».

Le LRMF (Laboratoire de Recherche des Musées de France), qui avait alors le statut d'unité mixte de recherche CNRS/ Ministère de la Culture (UMR 171), a participé, à l'initiative de Christian Lahanier, à plusieurs programmes de recherche ${ }^{4}$ sur la numérisation en haute définition des clichés photographiques et radiographiques, à la télétransmission des fichiers numériques résultant de ces travaux, à l'imagerie multi-spectrale, au traitement et à la fusion d'images. Cette série a commencé en 1989 avec les projets VASARI puis NARCISSE. La base de données résultant du projet NARCISSE est en ligne sur le site web du Ministère de la Culture (http://www.culture. gouv.fr/documentation/lrmf/pres.htm).

Jean-Claude Dran, responsable de l'équipe AGLAE, a développé avec son équipe deux réseaux COST $^{5}$. L'action COST G1, consacrée à «L'application de l'analyse par faisceaux d'ions aux objets d'art et archéologiques ", lancée en 1992 par Michel Menu, était la première action COST consacrée à la recherche sur le patrimoine culturel, organisée peu de temps après le lancement d'AGLAE et constituée autour d'un noyau initial avec deux laboratoires de Florence et d'Oxford. Elle s'est déroulée sur 5 ans avec la participation d'institutions de 12 pays. Puis l'action COST G8, au spectre de techniques plus large "Analyse et examen non destructif d'œuvres de musée ", de 2001 à 2005, comprenait 21 pays.

Ces deux réseaux ont établi la notoriété de l'équipe AGLAE dans le monde de l'analyse élémentaire par faisceaux d'ions des œuvres et des matériaux du patrimoine culturel et ont permis de créer des liens forts avec des partenaires européens.

Outre le LRMF, il faut signaler qu'en parallèle, le LRMH (Laboratoire de Recherche des Monuments Historiques) et le CRCDG (Centre de Recherches sur la Conservation des Documents Graphiques, devenu depuis le CRCC) ont été impliqués également dans de nombreux programmes européens dans leur domaine de compétence respectif. has been concretised in many calls of proposal. Michel Chapuis (Directorate-General for Research and Innovation), has published a synthesis of such projects. About 100 projects have been financed during the period 1991-2009, in the frame of the 3rd to 7th FPs ${ }^{1}$. One can access to the details of these projects on the Cordis website ${ }^{2}$, which represents a very rich source, in order to build up collaborations or to get research results...

In parallel, an inter-government structure created in 1971, called COST (European Cooperation in Science and Technology ${ }^{3}$, grouping together 36 countries, has supported networks between European research laboratories. Among them, some were dedicated to issues concerning "sciences and techniques dedicated to the cultural heritage".

The LRMF (Laboratoire de Recherche des Musées de France), which had the status of a common research laboratory between CNRS and the Ministry of Culture, participated to several projects initiated by Christian Lahannier and devoted to high definition digitisation of photographs or radiographs, teletransmission of the resulting digital files, multi-spectral imaging techniques, image processing ${ }^{4}$. This started in 1989 with the VASARI and NARCISSE projects. The database resulting from the NARCISSE project is still available on the website of the Ministry of Culture (http://www.culture.gouv.fr/documentation/lrmf/pres.htm).

Jean-Claude Dran, in charge of the AGLAE team, developped with his team two COST actions ${ }^{5}$. COST G1, dedicated to "The applications of ion beam analysis for art and archaeology artefacts", launched in 1992 by Michel Menu, was the first COST action devoted to cultural heritage subjects and was organised very soon after AGLAE was launched. It was composed by an initial core with two laboratories in Florence and Oxford. It took place during 5 years, with the participation of institutions from 12 countries. Then COST G8, with a larger spectrum of techniques "Analysis and nondestructive examination of museum objects » from 2001 to 2005, with participants from 21 countries!

These two networks have established the AGLAE team's fame among the community of ion beam elemental analysis of artefacts and materials of the cultural heritage and have procured the possibility to create strong links with European partners.

As well as the LRMF, one must mention that in parallel the LRMH (Laboratoire de Recherche des Monuments Historiques) and the CRCDG (Centre de Recherches sur la Conservation des Documents Graphiques, presently named CRCC) were involved in European research projects, in their respective areas of competence. 


\section{Le réseau LabS TECH}

\section{Origine du réseau}

L'Italie a été l'initiatrice d'un réseau national dédié à la science de la conservation, piloté par le CNR (Consiglio Nazionale delle Ricerche, équivalent du CNRS français) : Progetto finalizzato beni culturali (1996-2000). La France s'en est inspirée avec la création du réseau CHIMART, sous la forme d'un GdR (Groupement de Recherche) piloté par le CNRS, regroupant une trentaine de laboratoires (2000-2008), suivi par ChimARC (2008-2011), et qui a contribué à ouvrir les relations entre institutions patrimoniales, universités, écoles d'ingénieurs, laboratoires de recherche. En Espagne, le CSIC (Consejo Superior de Investigaciones Científicas, également équivalent du CNRS) a créé le Red de Ciencia y Tecnología para la Conservación del Patrimonio (http://www.rtphc.csic. es), qui est toujours actif.

En 1999, se tint à Paris une réunion des Ministres en charge de la Recherche des pays membres du G7. À cette occasion, une visite du laboratoire du C2RMF, service à compétence nationale né l'année précédente de la fusion du LRMF et du Service de restauration des musées de France, a été organisée. À la suite de cette visite germa l'idée de mettre en commun les moyens et les talents d'institutions actives dans le domaine de la conservation du patrimoine, issues des pays participants. Les arguments majeurs avancés étaient que ces institutions travaillent sur des collections similaires dont le volume est considérable, que les budgets publics de recherche et développement ne sont pas croissants et qu'il existait des complémentarités de moyens et/ou de compétences entre les participants potentiels. De plus, dans ce domaine de recherche, il n'existe pratiquement aucun risque de conflit de propriétés intellectuelle ou industrielle. Enfin, il était vraisemblable que la Commission européenne pourrait regarder avec bienveillance une démarche collective structurée.

À la suite de quoi, nos collègues italiens de l'Université de Pérouse, Antonio Sgamellotti et Bruno Brunetti, ont rédigé une première ébauche de ce qui allait devenir le réseau LabS TECH.

\section{Le réseau LabS TECH, son organisation, ses objectifs}

Ce réseau, intitulé LabS TECH (Laboratories on Science and Technology for the Conservation of European Cultural Heritage - Ref.: HPRI-CT-2000-40018), a démarré en janvier 2001 et s'est terminé en juin 2004.

Il a été coordonné par le Professeur Bruno Brunetti de l’Université de Pérouse - Département de Chimie.

Onze institutions de 8 pays participèrent à ce réseau (voir détails dans l'introduction, Tableau 1).

Les principaux objectifs ont été de :

- collecter et diffuser l'information sur les institutions actives en Europe, dans les domaines de la recherche et de la mise en œuvre des techniques d'examen et d'analyse appliquées aux ouvres du patrimoine culturel, conduisant à une

\section{The LabS TECH network}

Origin of the network

Italy was the initiator of a national network dedicated to the conservation science, driven by the CNR (Consiglio Nazionale delle Ricerche): Progetto finalizzato beni culturali (19962000). In France, we drew our inspiration from this and created the CHIMART network, as a GdR (Research Group) driven by the CNRS, including about 30 laboratories (20002008) which has contributed to open relations between cultural heritage institutions, Universities, various other research laboratories. In Spain, the CSIC (Consejo Superior de Investigaciones Científicas) has created the Red de Ciencia y Tecnología para la Conservación del Patrimonio (http:// www.rtphc.csic.es) which is still active.

In 1999, a meeting of the Ministries in charge of research of the G7 member states was held in Paris. On this occasion, a visit of the C2RMF laboratory was organised. Immediately after this visit, germinated the idea to put together and share the means and the skills of institutions of the G7 countries active in this field. The main arguments were:

- these cultural heritage institutions have been working on similar collections.

- the size of these collections are huge.

- the R\&D public funds were not increasing (in 1999, we did not foresee that they would be plainly decreasing !).

- in this research area, there nearly does not exist any risk of intellectual or industrial property conflict.

- very likely, complementarities exist in terms of equipment and/or know-how between the potential participants.

- the restoration calls for tender were yet open to European competitors.

- at least, it was likely that the European Commission will give favourable consideration to such a collective structured initiative.

Following this, our Italian colleagues of the Perugia University, Antonio Sgamellotti and Bruno Brunetti wrote a first draft of what will become the LabS TECH network.

\section{The LabS TECH network, its organisation, its goals}

This network, called LabS TECH (Laboratories on Science and Technology for the Conservation of European Cultural Heritage - Ref.: HPRI-CT-2000-40018) started in January 2001 and ended in June 2004.

The coordinator was Professor Bruno Brunetti of the University of Perugia, Department of Chemistry.

Eleven Institutions from 8 countries were participating in this network (see details in Introduction, Table I).

The main goals were:

- to collect and distribute information on European institutions involved in the areas of research and implementation of examination and analysis techniques applied to cultural heritage, leading to a better knowledge of the artefacts 
meilleure connaissance de la structure et de la composition des œuvres, des modifications ou altérations subies au cours du temps, permettant d'établir des bases scientifiques pour leur conservation et restauration.

- accroître le niveau de la recherche, en favorisant le travail en commun pour améliorer l'efficacité globale, en particulier par le biais d'un accès facilité aux installations les plus performantes.

- harmoniser les procédures, mettre au point et diffuser des pratiques recommandées, voire des normes.

- former des jeunes scientifiques.

- mettre sur pied des programmes de recherche et développement communs.

- élaborer de nouveaux procédés et/ou matériaux pour la conservation-restauration des œuvres.

- enfin, définir les bases de ce que pourrait être à moyen et long terme une structure de recherche européenne dédiée au patrimoine culturel, répartie, ouverte et intégrant des installations lourdes de recherche.

\section{Principaux résultats - Bilan}

Une enquête a été diffusée auprès de 225 institutions actives en recherche sur la conservation du patrimoine culturel. Au terme du projet, 114 institutions de 26 pays ont répondu à cette enquête. Les plus fortes contributions provenaient d'Italie, de France, d'Allemagne, du Royaume-Uni, de Grèce, du Portugal, de Belgique, d'Espagne, des États-Unis... Les institutions participantes étaient diverses : universités ou établissements d'enseignement supérieur, organismes publics de recherche, musées, institutions culturelles publiques, centres de restauration...

Une base de données a été créée, rassemblant les principales caractéristiques de ces institutions : personnel affecté, types de collections concernées, matériaux étudiés, techniques mises en œuvre... Ces informations montrent que la palette des techniques est très vaste, que même les grands laboratoires ne peuvent mettre en œuvre toutes ces techniques, ce qui justifie donc l'intérêt du travail en réseau. Ce travail de recensement a été poursuivi dans le projet Eu-ARTECH (2004-2009).

Un site internet a été créé, enrichi et mis à jour tout au long du projet ${ }^{6}$.

De nombreuses institutions ont appris à se connaître et à travailler ensemble, à échanger des expériences, des collaborateurs, à parler un langage commun...

Des documents de synthèse ont été élaborés et diffusés à propos de différentes thématiques : analyse des alliages à base de cuivre, analyse des pigments, analyse des liants organiques, caractérisation de la pierre, recensement des collections de matériaux de référence disponibles, inventaire des protocoles d'examen des œuvres avant restauration, ainsi que des protocoles de restauration (peintures de chevalet, peintures murales, œuvres en métal, œuvres en pierre)... structure and composition, of the modifications or suffered alterations along their history, permitting to establish scientific basis for their conservation and restoration.

- to raise the research level, through collaborative work, improving the global efficiency, particularly through an easier access to the best large research facilities.

- to harmonise procedures, settle and distribute best recommended practices and/or standards.

- to facilitate young scientists training.

- to set up cooperative R\&D projects dedicated to this area.

- to work out new conservation/restoration processes and/or materials.

- at least, to define what could be, at short or mean term, the basements of a European cultural heritage research structure, distributed, open and integrating large research facilities.

\section{Main results - Assessment}

A survey was distributed to 225 institutions active in conservation science. At the end of the project, 114 institutions from 26 countries completed the survey. The more important contributions were from Italy, France, Germany, United Kingdom, Greece, Portugal, Belgium, Spain, United States...

The participating institutions were diverse: Universities, public research institutions, public cultural institutions, museums, restoration workshops, technical centres, libraries...

One has created a database, collecting the main characteristics of these institutions: staff, concerned types of collections, studied materials, operated techniques... This information show clearly that the palette of techniques is quite large, and that even the large laboratories are not able to operate all these techniques, which justifies the interest of such a networking. This inventory work was continued during the Eu-ARTECH project.

A website was implemented and periodically updated during the project life ${ }^{6}$.

Many institutions got the possibility to discover each other and learned to work together, exchange experience and coworkers, and also share a common language.

Synthesis documents were edited and distributed relative to various sets of themes: analysis of copper based alloys, of pigments, of organic binders, characterisation of stones, inventory of available reference materials collections, inventory of procedures of artefact examination before restoration as well as restoration protocols (easel paintings, mural paintings, metal artefacts, stone artefacts)...

A collaboration with the Museum of Fine Arts (Boston) started, with the goals of enlargement and «Europeanisation » of $\mathrm{CAMEO}^{7}$ (Conservation and Art Materials Encyclopaedia Online). This task will continue in the frames of Eu-ARTECH and CHARISMA projects (see M. Derrick in this issue).

LabS TECH has also contributed in the elaboration of the working programme of the newly created Technical 
Une collaboration avec le Museum of Fine Arts (Boston) a été initiée, ayant comme objectif une extension et une « européanisation » de $\mathrm{CAMEO}^{7}$ (Conservation and Art Materials Encyclopaedia Online). Cette action sera poursuivie dans le cadre des projets Eu-ARTECH, puis CHARISMA (voir l'article de M. Derrick dans ce volume).

LabS TECH a participé à l'élaboration du programme de travail du nouveau Comité Technique du CEN (CEN/ TC-346) qui, désormais, élabore des normes européennes dans le domaine de la conservation du patrimoine culturel. Depuis sa première réunion de travail en juin 2004, ce comité a édité un nombre significatif de normes (13 publiées, 8 en circulation pour approbation, 1 en cours de rédaction).

\section{Pourquoi développer de nouveaux outils d'examen ou d'analyse pour les mettre à la disposition du monde de la conservation/ restauration?}

Les initiateurs de LabS-Tech ont réalisé un bilan des techniques d'examen et d'analyse mises en œuvre dans ce domaine, et ont défini deux axes à explorer :

- ouvrir l'accès à des installations lourdes repoussant les limites de détection en analyse ou fournissant de nouvelles informations sur la composition des objets, la provenance des matériaux... (AGLAE puis FIXLAB).

- mettre à disposition des conservateurs et/ou des restaurateurs des appareils portables ou transportables permettant d'effectuer des mesures sur des chantiers de fouilles archéologiques, dans les monuments historiques, les musées, bibliothèques, salles d'archives, ateliers de restauration (MOLAB).

\section{A. Faciliter l'accès aux installations lourdes utilisées jusque-là presque exclusivement par les chercheurs en physique}

Pour Eu-ARTECH (2004), AGLAE, seul accélérateur déjà dédié aux méthodes d'analyse par faisceau d'ions (IBA, PIXE, RBS...) des œuvres du patrimoine culturel a permis d'ouvrir le champ des méthodes de laboratoire conventionnelles (FRX, DRX, MEB-EDS...). Les limites de détection en analyse élémentaire sont significativement améliorées (par exemple la limite de détection du fer dans une matrice céramique passe de 100 ppm en FRX conventionnelle à 5 ppm en analyse PIXE). On peut s'intéresser à la micro-analyse (mesure sur un spot de 20 à $30 \mathrm{~mm}^{2}$ ), effectuer des analyses de surface, accroître le domaine expérimental en allant vers les éléments à numéro atomique faible ( $\mathrm{Na}, \mathrm{Mg}, \mathrm{Al} \ldots)$.

Dans le cadre de CHARISMA (2009), FIXLAB a été étendu à d'autres installations :

- un synchrotron (SOLEIL et la plateforme IPANEMA) qui délivre des faisceaux de photons monochromatiques (de l'infrarouge lointain aux photons $\mathrm{X}$ de $80 \mathrm{keV}$ ), focalisés et
Committee of the CEN (CEN/TC-346), which from now on works out European standards concerning the "Conservation of Cultural Heritage”. Since its first meeting in June 2004, this Committee has edited a significant number of standards (13 published, 8 in circulation for approval, 1 at draft status).

\section{What are the arguments for developing new examination or analysis tools and setting them at the disposal of the conservation/restoration community?}

The Initiators of LabS-Tech, after having completed an assessment of such techniques applied in this area, defined two tracks to be explored:

- facilitate the access to large research infrastructures, extending the detection limits in analysis, or providing new information about the structure of objects, or the provenance of materials... (AGLAE, and then FIXLAB).

- provide portable or transportable instrumentation at the disposal of curators, conservators and restorers, giving them the opportunity to realise on site measurements in archaeological excavations, historical buildings, museums, libraries, archive institutions, conservation workshops (MOLAB).

\section{A. Facilitate the access to large research infrastructures up to then used nearly exclusively by physicists}

For Eu-ARTECH, AGLAE, the only accelerator yet dedicated to IBA (PIXE, RBS...) of cultural heritage artefacts, permitted to broaden the field of conventional methods (XRF, XRD, SEM-EDS...). The detection limits in elementary analysis were significantly improved (for instance the detection limit of iron concentration in a ceramics matrix went from 100 ppm by conventional XRF analysis, down to 5 ppm by PIXE analysis. One can also be interested in micro-analysis (measurement spot of 20-30 $\mu^{2}$ ) or surface analysis and enlarging the experimental domain, reaching low $\mathrm{Z}$ elements $(\mathrm{Na}, \mathrm{Mg}$, Al...).

In the frame of CHARISMA, FIXLAB was extended to other infrastructures:

- a synchrotron (SOLEIL) which delivers monochromatic (from far infrared up to $80 \mathrm{keV}$ X-rays), focused and intense beams of photons (up to 10 billion times more intense than those delivered by the best X-ray tubes used for XRF analysis), permitting to carry out studies of speciation, composition or structure, going further in detection limits and/or on smaller examination volumes (2D mapping, 3D micro-tomography).

- a nuclear research reactor (BNC) providing external neutron beams. The interactions of neutrons with matter are quite different from those of photons or charged particles (protons, deuterons...) offering a range of possibilities to 
intenses (jusqu'à 10 milliards de fois plus brillants que les meilleurs tubes X utilisés en AFX), permettant de mener des études de spéciation, de composition et de structure, d'aller plus loin en limite de détection et/ou sur des volumes d'examen plus petits (cartographie, micro-tomographie...).

- un réacteur nucléaire de recherche (BNC) délivrant des faisceaux de neutrons dont les modes d'interaction avec la matière sont totalement différents de ceux des photons $\mathrm{X}$ ou des particules chargées (protons, deutons...) offrant une gamme de possibilités d'exploration de la composition ou de la structure des œuvres. Ainsi, la spectrométrie des photons gamma prompts émis lors de réactions $(\mathrm{n}, \mathrm{g})$ permet des analyses élémentaires globales. Tandis que la diffraction neutronique (diffusion élastique) permet de fournir des talline/amorphe, répartition des phases, contraintes mécaniques, impuretés) de métaux, verres, roches et ainsi de remonter à leur mode d'élaboration. La neutronographie ou la tomo-neutronographie permettent d'obtenir dans certains cas des informations différentes et complémentaires de celles fournies par la radiographie X ou gamma.

Le tableau I donne les principales caractéristiques de ces méthodes d'analyse.

\section{B. En géologie, en prospection minière, l'utilisation d'appareils portables ou transportables relève de la routine}

Dans le domaine du patrimoine culturel, il existait un manque. Soit les appareils étaient peu adaptés, soit la communauté conservation/restauration était peu familiarisée à des

explore the compositional or structural features of artefacts. Capture-like phenomena can reveal, by the detection of characteristic $\gamma$-photons produced in $(n, \gamma)$ reaction, the bulk elemental composition of the objects. Neutron diffraction (elastic scattering) patterns will permit to give indications on the atomic, molecular or nano-scale structural properties. Thus crystalline/amorphous morphology, phase composition, mechanical strains, impurities, etc. can be revealed on metallic, glassy, or stone objects and so returning to their elaboration process. Neutron radiography and tomography will in some cases give different and complementary information from that given by X-ray or gamma radiography.

Table I gives summary of the main characteristics of these analytical methods.

\section{B. In geology or in mining prospecting, the use of portable or transportable instrumentation is a routine practice}

In the cultural heritage area, one observed a lack of such a practice. Either the devices were not appropriate, or the conservation community was not familiar with such potentially useful existing equipment. It is obvious that on site measurements (on excavations, historical buildings, museums, libraries and restoration workshops) present a major interest.

So, in the frame of Eu-ARTECH and then CHARISMA, MOLAB's goal was to adapt and propose to end users teams various devices (elemental analysers, molecular analysers, imaging devices at various wavelengths...) operated by teams mastering those techniques and familiar with the cultural heritage issues.

Tableau I. Caractéristiques comparées des méthodes d'analyse utilisant des rayonnements ionisants

\begin{tabular}{|l|l|l|l|}
\hline Comparative characteristics for elemental analysis with ionising radiations & $\begin{array}{l}\text { Mobile } \\
\text { (Y/N) }\end{array}$ & $\begin{array}{l}\text { Typical limit of detection } \\
\text { (ex.: iron in ceramic matrix) }\end{array}$ \\
\hline Technique & Type of analysis & N & $100 \mathrm{ppm}$ \\
\hline X-ray fluorescence/wavelength dispersion & on sample - surface (about $10 \mu \mathrm{m}$ to $100 \mu \mathrm{m}$ depth) & Y & 0,05 to $0,1 \%$ \\
\hline X-ray fluorescence/energy dispersion & on sample - surface (about $10 \mu \mathrm{m}$ to $100 \mu \mathrm{m}$ depth) & N & $100 \mathrm{ppm}$ \\
\hline SEM-EDX & on sample - surface (about $1 \mu \mathrm{m}$ to $10 \mu \mathrm{m}$ depth) & $\mathrm{N}$ & $5 \mathrm{ppm}$ \\
\hline PIXE & $\begin{array}{l}\text { on the object - surface (some mm to some } 100 \mathrm{~mm} \\
\text { depth) }\end{array}$ & N & $5 \mathrm{ppm}$ \\
\hline SR-XRF & on the object - surface (about $10 \mu \mathrm{m}$ to $1 \mathrm{~mm}$ depth) & $\mathrm{N}$ & 100 to $1000 \mathrm{ppm}$ \\
\hline PGAA & on the object - global & $\begin{array}{l}\text { on the object - grazing incidence - on sample - } \\
\text { on crushed sample }\end{array}$ & $5 \%$ \\
\hline XRD & & Y & 5 \\
\hline
\end{tabular}


techniques existantes potentiellement utilisables. Or les mesures sur site (chantiers de fouilles, monuments historiques, musées, bibliothèques, salles d'archives, ateliers de restauration) présentent un réel intérêt.

Dans le cadre de Eu-ARTECH, puis de CHARISMA, MOLAB a donc visé à adapter et mettre à disposition des matériels divers (analyse élémentaire, analyse moléculaire, imagerie à diverses longueurs d'onde...) mises en œuvre par des équipes maîtrisant ces techniques et familières des problématiques du patrimoine culturel.

MOLAB a aussi innové en mettant en œuvre des outils nouveaux développés dans la partie R\&D des projets Eu-ARTECH et CHARISMA (mini-tomographe de résonance magnétique nucléaire, spectromètre infrarouge/Raman, analyseur de fluorescence de rayons $\mathrm{X} /$ diffractomètre de rayons X...).

Au cours des très nombreuses campagnes menées à bien par des équipes très diverses, l'expérience accumulée avec tous ces outils, ajoutée à la grande diversité d'œuvres, de matériaux, de conditions d'emploi... a ouvert et validé un champ nouveau de pratiques.

\section{Eu-ARTECH - Access Research et Technology for the Conservation of the European Cultural Heritage, Ref. RII3-CT-2004-506171 \\ (juin 2004-mai 2009)}

À partir des résultats obtenus dans le cadre de LabS TECH, en tenant compte de l'état de développement des techniques, des synergies existantes entre certaines institutions, un nouveau projet de 5 ans, intitulé Eu-ARTECH (Access Research et Technology for the Conservation of the European Cultural Heritage) a été approuvé, coordonné par l'Université de Pérouse, en tant qu' « Initiative d'Infrastructure Intégrée » du $6^{\mathrm{e}}$ PCRD.

Le coordonnateur du projet était le Professeur Bruno Brunetti, Université de Pérouse (Italie), Département de Chimie. Treize institutions de 7 pays étaient membres du consortium (voir détails dans l'introduction, Tableau I).

L'objectif de ce projet était de constituer un réseau permanent opérationnel entre les différents partenaires afin d'établir des coopérations et des échanges de savoirs avec l'ensemble des institutions de recherche et de conservation européennes. Y collaborent physiciens, chimistes, spécialistes des matériaux, conservateurs, archéologues, historiens d'art, restaurateurs... Le projet se structure autour de trois activités, la mise en réseau des connaissances et des bonnes pratiques, l'accès transnational à des équipements scientifiques de pointe, et les recherches coordonnées visant à renforcer et améliorer l'accès transnational.
MOLAB has also innovated by the use of new equipment developed in the R\&D task of the Eu-ARTECH and CHARISMA projects (nuclear magnetic resonance mini-tomograph, infrared/Raman spectrometer, X-ray fluorescence/X-ray diffraction analyser...).

In the process of the large number of examination campaigns carried on by quite different teams, the accumulated experience with all these tools, in conjunction with the encountered large palette of artefacts and materials and of various usage conditions has validated a broad new field of practices.

\section{Eu-ARTECH - Access Research and Technology for the Conservation of the European Cultural Heritage, Ref. RII3-CT-2004-506171}

(June 2004-May 2009)

Starting from the results obtained in the frame of LabS TECH, taking in account the development level of various techniques, the existing synergies between potential partner institutions, a 5 years long new project called Eu-ARTECH (Access Research and Technology for the Conservation of the European Cultural Heritage) was approved, as an «Integrated Infrastructure Initiative " of the 6th FP.

The coordinator was Prof. Bruno Brunetti, University of Perugia (Italy), Department of Chemistry.

Thirteen institutions of 7 countries took part in this project (see details in Introduction, Table I).

The purpose of this project was to build up a long lasting operational network between the various partners, in order to establish cooperation and knowledge exchange with the whole European communities of research and cultural heritage. Different types of profiles contribute to the project: physicists, chemists, material specialists, curators, archaeologists, art historians, conservators-restorers... The project is structured in three activities: networking for knowledge and good practices, transnational access and joint research activity so as to strengthen and improve the transnational access.

\section{Networking and knowledge distribution, in the continuity of LabS TECH}

Eu-ARTECH's aim consists in promoting and exchanging knowledge, distributing good practices in conservation science, establishing common protocols, contributing to the elaboration of European standards...

In order to share knowledge and resources in the area of examination and analysis of artefact san effort was done in order to identify the actors and their know-how and distribute the information produced by the consortium. At the end of the project, 600 correspondents from 363 institutions among 47 countries (of the 5 continents!) were registered on the distribution list of the project's periodical newsletter: Universities, public research institutions, museums, cultural 


\section{Mise en réseau et la diffusion des connaissances et des bonnes pratiques}

Eu-ARTECH vise à promouvoir et échanger les connaissances, diffuser de bonnes pratiques en matière de conservation, définir des protocoles communs, contribuer à l'élaboration de normes européennes...

À la fin du projet, 600 correspondants de 363 institutions réparties sur 47 pays (des 5 continents) étaient enregistrés sur la liste de diffusion: universités ou établissements d'enseignement supérieur, établissements publics de recherche, musées, institutions publiques patrimoniales, ateliers de restauration, constructeurs d'instrumentation, bibliothèques, collectivités territoriales...

L'enquête débutée dans le cadre de LabS TECH, relative aux techniques d'examen et d'analyse des ouvres et des matériaux constitutifs a été étendue et mise à jour tout au long du projet. À son terme, 151 institutions ou entreprises ont contribué à l'élaboration de cette base de données. Le tableau II donne la liste et la fréquence d'utilisation des techniques les plus utilisées (114 au total).

Pour valoriser ses résultats, Eu-ARTECH a organisé des conférences internationales, des écoles pratiques et des séminaires thématiques, dont la majorité a fait l'objet de publications ${ }^{12}$ à 20 . Pour d'autres, des documents sont accessibles sur le site web du projet ${ }^{11}$. Les principaux sujets traités ont été les techniques d'analyses non destructives, l'analyse des colorants, les applications de la résonance magnétique nucléaire (RMN) dans le domaine du patrimoine culturel, les techniques de la peinture ou des céramiques de Della Robbia, ou encore les méthodes de monitoring des surfaces architecturales.

Lors de la réunion finale du projet dans les locaux de l'ICN, à Amsterdam, les participants ont présenté en fonctionnement tous les outils d'examen ou d'analyse mis en ouvre lors des différentes campagnes de mesure sur sites et ceux développés dans les actions de

\section{Tableau II. Fréquence d'utilisation des techniques}

Enquête effectuée dans le cadre des projets européens LabS TECH et Eu-ARTECH. (N.B. : 114 techniques mentionnées par 151 institutions participantes).

\begin{tabular}{|c|c|c|}
\hline \\
\hline Rank & \multicolumn{2}{|l|}{ Most frequently used techniques (LabS TECH and Eu-ARTECH } \\
\hline 1 & Reflection Light Microscopy & 107 \\
\hline 2 & Transmission Light Microscopy & 99 \\
\hline 3 & Classical Visible Light Digital Photography & 91 \\
\hline 4 & Scanning Electron Microscopy (SEM) & 89 \\
\hline 5 & Classical Visible Light Silver Emulsion Photography & 73 \\
\hline 6 & Infrared Spectrometry & 73 \\
\hline 7 & Visible and Ultraviolet Spectrometry & 60 \\
\hline 8 & Diffractometry & 57 \\
\hline 9 & Standard Colorimetry & 57 \\
\hline 10 & Ultraviolet Fluorescence Photography & 57 \\
\hline 11 & Powder Diffractometry & 56 \\
\hline 12 & Low HV $(<150 \mathrm{kV})$ X-ray Radiography & 53 \\
\hline 13 & Environmental Weathering Tests (Chambers) & 52 \\
\hline 14 & Infrared Spectrometry Microscopy & 52 \\
\hline 15 & Digitisation and Image Archiving & 49 \\
\hline 16 & Gas Chromatography (GC) & 43 \\
\hline 17 & High Performance Liquid Chromatography (HPLC) & 42 \\
\hline 18 & Gas Chromatography - Mass Spectrometry (GC-MS) & 41 \\
\hline 19 & Infrared Silver Emulsion Photography & 41 \\
\hline 20 & Differential Thermal Analysis (DTA / TG / DTG) & 40 \\
\hline 21 & X-ray Fluorescence Analysis - X-ray Tube - Laboratory Fixed Instrument & 39 \\
\hline 22 & Universal Mechanical Testing & 39 \\
\hline 23 & Low Angled Photography & 39 \\
\hline 24 & Infrared Reflectography Electronic Camera & 39 \\
\hline 25 & Spectro-Photo-Colorimetry & 38 \\
\hline 26 & Accurate Colour High Resolution Digital Photography & 36 \\
\hline 27 & High voltage $(150<\mathrm{HV}<450 \mathrm{kV})$ X-ray Radiography & 33 \\
\hline 28 & Ion Chromatography & 32 \\
\hline 29 & Raman Spectrometry & 32 \\
\hline 30 & X-ray Fluorescence Analysis - X-ray Tube - Portable & 30 \\
\hline 31 & Thin Layer Chromatography (TLC) & 29 \\
\hline 32 & Atomic Emission spectrometry (ICP-AES) & 28 \\
\hline 33 & Electron Microprobe & 27 \\
\hline 34 & Atomic Absorption Analysis (AAA) & 26 \\
\hline 35 & Environmental Natural Weathering Tests (Outdoor) & 26 \\
\hline 36 & Pyrolysis Gas Chromatography (Py-GC) & 22 \\
\hline 37 & Mercury Porosimetry & 22 \\
\hline 38 & Particle Induced X-ray Emission (PIXE) & 21 \\
\hline 39 & Pyrolysis Gas Chromatography - Mass Spectroscopy (Py-GC-MS) & 18 \\
\hline 40 & Environmental Scanning Electron Microscopy (ESEM) & 18 \\
\hline
\end{tabular}




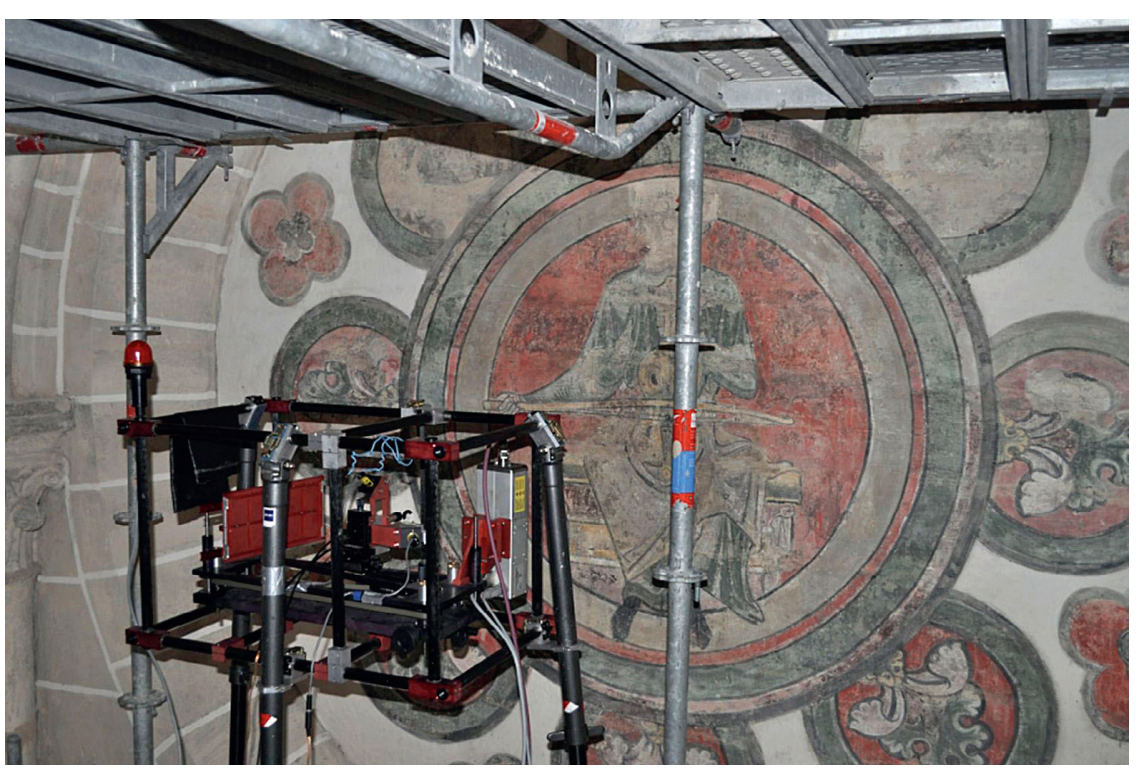

Fig. 2. Appareillage de diffraction de rayons $\mathrm{X}$ et fluorescence X développé dans le cadre de Eu-ARTECH en position d'analyse devant une peinture murale du XIII ${ }^{\mathrm{e}}$ siècle de la cathédrale de Chartres. X-ray diffraction and $X$-ray fluorescence device developed in the framework of the Eu-ARTECH project positioned for analysis in front of a 13 th $c$. mural painting of the Chartres cathedral. () LRMH/V. Detalle.

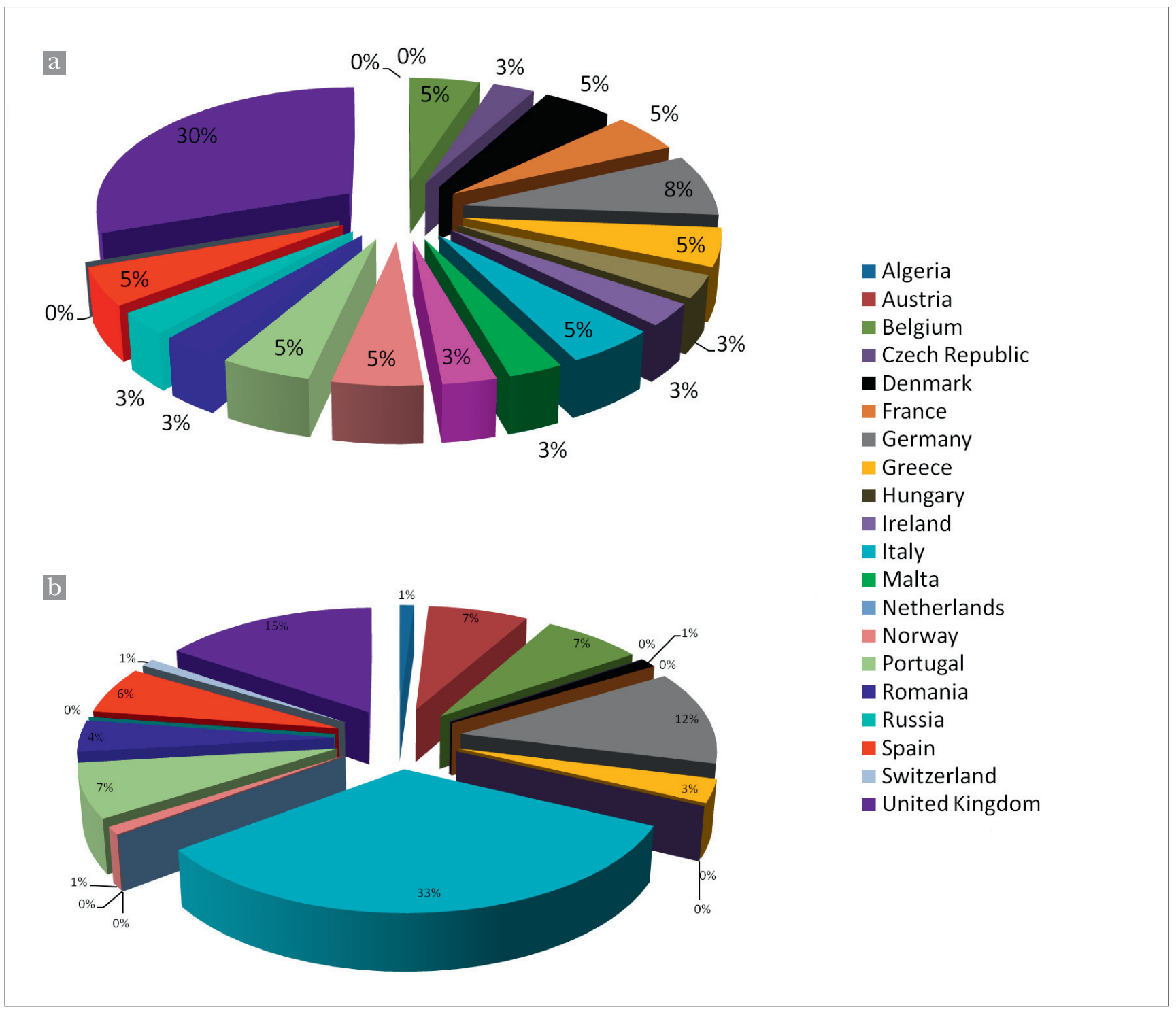

Fig. 3. Représentation du taux de projets par pays pour l'activité de a) MOLAB et b) AGLAE. Representation of the project number ratio per country for a) the MOLAB and b) AGLAE activities. 
recherche, ceci sur des œuvres réelles, ainsi que des posters sur toutes les autres activités menées à bien dans le cadre du projet. Cette journée était ouverte à la presse, aux institutionnels et aux étudiants.

Le partage de connaissance et de bonnes pratiques comportait également l'établissement de protocoles d'identification et d'analyse de colorants et de certains composés organiques, ainsi que la rédaction par un collectif d'un Manuel à l'usage des restaurateurs, consacré aux Examens scientifiques pour l'étude des peintures ${ }^{21}$.

\section{Accès aux infrastructures de recherche ou aux équipements d'analyse}

Deux accès transnationaux sont offerts par des partenaires du projet à des utilisateurs européens :

- AGLAE (Accélérateur Grand Louvre pour l'Analyse Élémentaire du C2RMF) destiné à l'ensemble des méthodes d'analyse par faisceaux d'ions, seul accélérateur au monde dédié au patrimoine culturel, où des équipes européennes non françaises ont pu bénéficier de $20 \%$ du temps de faisceau, afin d'effectuer des analyses PIXE, PIGE, RBS (fig. 1).

- MOLAB, bouquet de 10 instruments d'analyse portables ou transportables, mis au point ou adaptés par des laboratoires de recherche italiens (Université de Pérouse ; ICVBC, OPD et INOA à Florence), qui ont pu être utilisés sur des sites européens (monuments historiques, musées, bibliothèques, ateliers de restauration, chantiers de fouilles archéologiques...), afin d'effectuer des campagnes de mesure par des équipes de recherche en association avec les utilisateurs du monde du patrimoine : spectromètre infrarouge à fibres optiques, micro-spectromètre Raman, réflectomètre infrarouge, micro-profilomètre laser, analyseur par fluorescence $\mathrm{X}$, mini-tomographe RMN (résonance magnétique nucléaire), scanner infrarouge, instrument de mesure de résistance au percement (DRMS), spectromètre de fluorescence UV-VIS à fibres optiques, spectromètre de fluorescence dans le visible.

Ce concept est une "première ", au niveau des programmes de recherche européens et a probablement été un argument décisif dans le choix de la Commission.

Les campagnes de mesure se font après appels à propositions, qui sont évaluées et sélectionnées par un comité d'experts extérieurs au consortium (voir l'article C. Pacheco dans ce volume). Le nombre de jours de travail utiles pour les utilisateurs, sur la durée du projet, pour l'ensemble AGLAE et MOLAB, a été de 540. 105 études ont été réalisées et le nombre total d'utilisateurs a été de 305 . Des équipes utilisatrices de 20 pays ont profité de ces campagnes (voir fig. 3 pour le détail de la répartition). On notera la forte participation d'équipes d'Italie, du Royaume-Uni et d'Allemagne.

Outre les origines géographiques des équipes utilisatrices et le succès quantitatif rencontré lors des appels d'offres, il faut souligner l'efficacité et la disponibilité des équipes d'AGLAE et de MOLAB, la grande diversité des types d'œuvres étudiées et la grande diversité des matériaux analysés. heritage institutions, restoration workshops, instrumentation manufacturers, libraries, local authorities...

The survey, initiated in the frame of LabS TECH, dedicated to the examination and analysis techniques was extended and updated continuously. At the project's end, 151 institutions or enterprises have collaborated in this database. Table II gives the list and the frequency of use of the more used techniques (on a total number of 114).

The domains in which are involved the participants in the survey are quite different, as far as type of collections and studied materials are concerned.

In order to promote the results obtained in its frame, Eu-ARTECH organised international conferences, workshops, courses and thematic seminars, the majority of them lead to publications 12 to 20 . For others, documents are available on the project website ${ }^{11}$. The main concerned subjects were nondestructive analysis techniques, dyes analysis, nuclear magnetic resonance (NMR) tomography, paintings techniques, glazed ceramics techniques (Della Robbia) or monitoring methods of architectural surfaces.

At the occasion of the final meeting of the project, in the ICN premises in Amsterdam, the participants have presented, in working conditions, all the instruments employed during all the MOLAB campaigns (see chapter 3.2) and those developed during the cooperative research task (see chapter 3.3). This was done on real artefacts. Also posters on all the various tasks accomplished during the project were presented. This show was opened to the press, institutions' staff and students.

The sharing of knowledge and good practices also included the setting up of identification and analysis protocols of dyes and other organic components and the publication by a group of contributors of a book "Scientific examination for the investigation of paintings. A handbook for conservatorrestorers" 21

\section{Access to research infrastructures and to analytical instruments}

Two transnational accesses were proposed by members of the consortium to European end users:

- AGLAE, located in the C2RMF laboratory, close to the Louvre Museum in Paris. This was, in the world, the only accelerator dedicated to ion beam analysis of cultural heritage artefacts and materials. European teams (out of France) could benefit from $20 \%$ of the available beam time to complete the various palette of elemental analysis techniques (PIXE, PIGE, RBS...) (fig. 1).

- MOLAB, bunch of 10 portable or transportable analytical instruments, developed or adapted by Italian research laboratories (University of Perugia ; ICVBC, OPD and INOA in Florence). Such instruments could be used on various European sites (historical monuments, museums, libraries, restoration workshops, archaeological excavations...), to realise measurement campaigns by teams of the cultural 


\section{Projets de recherche coordonnée}

Parmi les thématiques retenues, on peut citer le développement et la validation d'instruments d'examen ou d'analyse portables ou transportables tels que la tomographie par résonance magnétique nucléaire (RWTH), l'imagerie multi-spectrale (INOA et OADC), la micro-spectrométrie Raman couplée à la spectrométrie de fluorescence dans le visible (Uni Pg). Le C2RMF a eu en charge la conception et la mise au point d'un système portable couplant analyse par fluorescence X et diffractométrie $\mathrm{X}^{23}$ (voir l'article de J. Castaing et al. dans ce volume) (fig. 2).

Il faut également mentionner la mise au point de nouveaux traitements de conservation pour des œuvres exposées en plein air : suivi de la corrosion du bronze (BLfD et LNEG), détérioration de la pierre (ICVBC, OPD et LNEC).

L'une des études collaboratives les plus intéressantes a été animée par Maarten van Bommel (ICN) et Jo Kirby (NGL) consacrée à la redécouverte des recettes de colorants naturels bleu (indigo), jaune (carthame, gaude, genêt des teinturiers) et rouge (bois du Brésil, cochenille, garance) et leur procédé de fixation sur différentes fibres textiles ou leur utilisation pour la production de laques ${ }^{22}$.

\section{Remerciements/Acknowlegments}

Tous ces échanges et ce travail en commun pour un patrimoine commun n'ont pu se réaliser que grâce à l'énergie communicative de Bruno Brunetti et à la participation amicale de :/ All these exchanges of information and this co-working for our common cultural heritage were made possible owing to the communicative energy of Bruno Brunetti and the friendly participation of:

S. Bittner, B. Blümich, S. Bracci, T. Calligaro, L. Cartechini, J. Castaing, Y. Chryssoulakis, J. Delgado, M. Derrick, A. de Tagle, J.-C. Dran, M.-D. Gayo, C. Higgitt, I. Joosten, J. Kirby, G. Lanterna, M. Mach, M. Matteini, M. Menu, C. Miliani, J. Mimoso, B. Moignard, L. Pezzati, J. Perlo, L. Pichon, D. Pinna, A. Pinto, S. Röhrs, A. Roy, J. Salomon, M. Schreiner, A. Sgamellotti, R. Snethlage, S. Sotiropoulou, M. Spring, L. Toniolo, M. van Bommel, M. van Bos, I. Vanden Berghe, J. Wadum et d'autres. Qu'ils en soient tous remerciés. Let us sincerely thank them. heritage community users together with scientific research teams: optical fibres infrared spectrometer, Raman microspectrometer, infrared reflectometer, laser micro profilometer, X-ray fluorescence analyser, mini-NMR tomograph, infrared scanner, drilling resistance measurement system (DRMS), optical fibres UV-vis fluorescence spectrometer, photo-spectrometer.

This concept was a «première ", for the European research projects and played probably a decisive argument when the Commission made his decision.

The measurement campaigns are done after call of proposals, which have been evaluated and selected by a committee of experts external to the consortium (see C. Pacheco in this issue). The total effective number of useful days for the whole project duration, for AGLAE and MOLAB together, was 540. 105 studies have been completed and the total number of users has been 305 .

User teams from 20 countries have taken benefit from these campaigns (see fig. 3 for the allotment). One can underline the important participation of user teams from Italy, United Kingdom and Germany.

Besides the geographical origins of the user teams and the quantitative success encountered at the occasion of the calls of proposal, one must underlined the efficiency and the availability of the AGLAE and MOLAB teams, and at least, the large diversity of artefacts and/or materials which have been analysed.

\section{Coordinated research projects}

Among the selected themes, one can mention:

Development and tests of portable or transportable instruments for examination or analysis: nuclear magnetic resonance (NMR) mini-tomograph (RWTH), multi-spectral imaging scanner (INOA and OADC), Raman micro-spectrometer coupled with UV-vis fluorescence (Uni Pg), X-ray fluorescence analyser coupled with X-ray diffractometer (C2RMF) ${ }^{23}$ (see also J. Castaing in this issue) (fig. 2).

Settling of new conservation treatments for open air exposed artefacts; following through bronze corrosion (BLfD and LNEC) or stone degradation (ICVBC, OPD and LNEC)

One of the most interesting studies was conducted by Maarten van Bommel (ICN) and Jo Kirby (NGL), dedicated to the re-discovery of preparation recipes of natural dyes: blue (indigo), yellow (safflower, weld, dyer's broom) and red (Brazil wood, cochineal, madder), their fixation processes on different textile fibres or their use for lacquer elaboration $^{22}$. 


\section{References}

1. M. Chapuis, Preserving our heritage, improving our environment, Vol. I, 20 years of EU research into cultural heritage, EUR 22050 EN, 2009. M. Chapuis, A. Lydon and A. Brandt-Grau, Preserving our heritage, improving our environment, Vol. II, Cultural heritage research: FP5, FP6 and related projects, EUR $22050 \mathrm{EN}, 2009$.

2. CORDIS, Community Research and Development Information Service, http://cordis.europa.eu/home_fr.html

3. COST, European Cooperation in Science and Technology, http://www.cost.eu

4. C. Lahanier, E-Culture Net - Network of centres of excellence for research and education in digital culture (European project IST-2001-37491),

http://www.eculturenet.org/data/FP5/ Internal/contributions/3/WP3C2RMF.pdf

5. A. Adriaens, G. Demortier, "COST Actions G1 and G8: EU programmes on the use of radiation in art and archaeometry", Nuclear Instruments and Methods in Physics Research B 226, 2004, 3-9.

6. LabS TECH European network, http://www.chm.unipg.it/chimgen/LabS-TECH.html

7. CAMEO - Conservation and Art Materials Encyclopedia Online http://cameo.mfa.org/wiki/Main_Page

8. B. Brunetti, C. Seccaroni, A Sgamellotti, "The painting technique of Pietro Vannucci called 'il Perugino'. Proceedings of the LabS Tech Symposium" (Perugia, April 2003), Florence, Nardini, 2004.
9. European standards relative to the conservation of cultural heritage, CEN/TC 346, http://standards.cen.eu/dyn/ $w w w / f ? p=204: 105: 0: \ldots::$

10. B. Brunetti and al., "Access Research and Technology for the conservation of the European Cultural Heritage", Final activity report, Eu-ARTECH project, Contract no: RII3-CT-2004-506171, 2009

11. Eu-ARTECH European project, http://www.eu-artech.org.

12. "Raphael's painting technique: working practices before Rome", Proceedings of the Eu-ARTECH workshop, National Gallery, London, November 2004 Ed. A. Roy and M. Spring, Quaderni di Kermes, 2007.

13. «La technique picturale de Matthias Grünewald and de ses contemporains »-Colmar, Musée d'Unterlinden and C2RMF - Janvier 2006. Ed. M. Menu and E. Ravaud, Technè hors-série, Paris, RMN, 2007.

14. "Theory and practice in conservation: a tribute to Cesare Brandi", Lisbon, LNEC, May 2006, Ed. J. Delgado and J. Mimoso, LNEC, 2006.

15. «De la peinture de chevalet à linstrument de musique : vernis, liants et couleurs ", proceedings of the colloquium, March 2007, Paris, Cité de la Musique, 2008.

16. "Small samples, big objects", proceedings of the Eu-ARTECH seminar BLfD, Munich, May 2007, Ed.. M. Mach, BLfD, 2007.
17. "Stone consolidation in cultural heritage: research and practice", Lisbon,LNEC, May 2008, Ed. J. Delgado and J. Mimoso LNEC, 2008.

18. "In situ monitoring of monumental surfaces”, Florence, ICVBC, October 2008 , Ed. P. Tiano and C. Pardini, proceedings of International Workshop SMW08, Edifir Edizioni, Florence, 2008.

19. "The painting technique of Andrea Mantegna”, Paris, Palais du Louvre, December 2008, Ed. M. Menu and E. Ravaud, Technè hors-série, Paris, RMN, 2009.

20. "Conservation of glazed ceramic tiles: research and practice", Lisbonne, LNEC, April 2009, Ed. J. Delgado and J. Mimoso, LNEC, 2009.

21. D Pinna, M Galeotti, R Mazzeo, Eds., Scientific examination for the investigation of paintings. A handbook for conservator-restorers European Project Eu-ARTECH, Florence, Centro Di della Edifimi, 2009.

22. J. Kirby, M. van Bommel, A Verhecken, "Natural colorants for dyeing and lake pigments: Practical recipes and their historical sources", London, Archetype, 2014.

23. A. Gianoncelli, J. Castaing and al., "A portable instrument for in situ determination of the chemical and phase composition of cultural heritage objects", X-Ray Spectrometry, vol. 37, 2008, p. $418-423$. 